\title{
ADVERTISING AGENCY MARKETING MANAGEMENT
}

\author{
Denis KISLOV', \\ National Academy of Public Administration under the President of Ukraine, Ukraine
}

Yevgenia HOROBEI²,

Atlantic Group, Ukraine

\begin{abstract}
Goal of the paper. The goal of this article is to define the nature, specific features and factors pertaining to the advertising agency marketing management. One of the tools is the use of non-standard approaches to management of advertising agencies, which under certain conditions makes it possible to improve the situation and to bring the agency to a new higher level as well as to improve the efficiency of its functioning in the conditions of transformational economy of Ukraine. Methodology. Monitoring of the marketing behavior of agencies that promote advertising services. The results of monitoring and analysis demonstrated that the majority of agencies have a disorganized approach to the agency marketing, which results in sporadic activities related to the use and organization of agency marketing. Only individual agencies begin to form their own marketing strategy for the implementation of which marketing budgets are allocated. The main marketing functions of a Ukrainian advertising agency have been identified. Practical value. Rapid development of technologies, sophistication and increased variety of goods and services, reduction of their life cycle, higher customer demands, the growth of volume and speed of obtaining information, increased competition - all these changes that are taking place in the external environment make the Ukrainian companies that provide advertising services search for new approaches to ensure better adaptation to these conditions. Uncertainty, unpredictability and instability of the external environment will continue to grow. Therefore, the companies that provide advertising services need to constantly adapt not only to the existing conditions but also ensure that they are able to quickly react in the future. The basic precondition for success is stability of the quality that is achieved through strategic planning, fine-tuned search system, efficient management, which encourages creation of a position of quality assurance director or manager, who would be responsible for the standards of client service quality. According to the monitoring results, agencies begin to form their own marketing strategies, for the implementation of which marketing budgets are allocated, which will facilitate the search for new customers. Relevance/originality. Based on the received data, further development of the advertising market may be determined by the development of other commodity markets, and first of all - by an increased volume of the consumer goods market.
\end{abstract}

Key words: sales volume, management of goods, pricing, marketing department, advertising services, advertising agency.

JEL Classification: M11, M13, M37

\section{Introduction}

In the course of time, the exchange process is improved by those involved in it. In other words, a company acquires professional skills of management of its marketing. Filip Kotler defines marketing management as "Analysis, planning, implementation and monitoring of activities designed for establishing, strengthening and maintaining profitable exchanges with target buyers for achieving certain objectives of the organization, such as profit, sales growth, increased market share, and so on" (Kotler 2006). Therefore, the essence of marketing management is to find the optimum number of customers necessary to sell all products produced by the company at a certain time. The task of marketing management is "to influence the level, time, and nature of demand in such a way as to help the organization to achieve the goals identified for it", which in other words means "Marketing management is demand management". In view of this, marketing management implies the study of a desired level of demand for products of a given company; analysis of the situation when actual demand is higher than the desired one, their correlation, and the situation when actual demand is lower than the desired one.

\footnotetext{
Corresponding author

${ }^{1}$ Department of Marketing and Advertising, National Academy of Public Administration under the President of Ukraine.

E-mail: kislov.denisv@gmail.com

${ }^{2}$ Master of Arts, Atlantic Group.

E-mail: evgenia.gorobey@ukr.net
} 
The process of marketing management encompasses such activities of a company as organization of sales and stimulation thereof, advertising campaigns and marketing studies, goods management and pricing. Rapid development of technologies, sophistication and increased variety of goods and services, reduction of their life cycle, higher customer demands, the growth of volume and speed of obtaining information, increased competition - all these changes that are taking place in the external environment make the Ukrainian companies that provide advertising services search for new approaches to ensure better adaptation to these conditions. Uncertainty, unpredictability and instability of the external environment will continue to grow. Therefore, the companies that provide advertising services need to constantly adapt not only to the existing conditions but also ensure that they are able to quickly react in the long-term perspective. In this situation, the importance of an efficient system of marketing of a company that provides advertising services grows.

The goal of this article is to study the specific features of a system for managing a company that provides advertising services.

The subject of the study is the marketing management process at companies that provide advertising services.

Results of the study. Under the influence of social or other interactions processes are constantly going on in the market that affect companies' market opportunities; these processes include changes of prices and rates for the basic goods or services, the related products or services, changes in the infrastructure, ethnographic, demographic, political and environmental changes, emergence of new or elimination of old economic structures and so on.

\section{Marketing Management Process}

Under the conditions of constant dialectic transformations in the society in general and in the market in particular, any company that wishes to have adequate demand for its products needs to know what the society or a certain part thereof really needs, and in what quantity, in a given place and at a given time. To receive such knowledge, it has to compare its goals against the market demands on a regular basis, and revise when necessary its strategic or tactical positions, develop operative steps, that is, exercise marketing management. Schematically, the marketing management process looks as follows:

\begin{tabular}{|c|c|c|c|c|c|}
\hline $\begin{array}{c}\text { analysis } \\
\text { of market } \\
\text { opportunities }\end{array}$ & $\theta$ & $\begin{array}{l}\text { selection } \\
\text { of target } \\
\text { markets }\end{array}$ & $\because 1$ & $\begin{array}{l}\text { development } \\
\text { of marketing } \\
\text { complex }\end{array}$ & $\begin{array}{c}\text { implementation } \\
\text { of marketing } \\
\text { measures }\end{array}$ \\
\hline
\end{tabular}

Fig. 1. Marketing Management Process (Ortins'ka, Dubovik T.\& Dubovik O.2003)

Let us look at the main functions and criteria for evaluating the work of Marketing unit employees (Table 1).

\section{Essays Advertising Business in Ukraine}

Development of advertising business in Ukraine as an independent branch largely depends on the level of organization of the current advertising services in the Ukrainian market and on the advertising forms selected by advertising agencies. Under the current conditions, advertising business is one of the branches of economy that combines tens of thousands of different economic actors. The efficiency of functioning of the Ukrainian economy as a whole depends to a large extent on how efficiently this system will work (Cherevko, 2004).

The post-industrial epoch that was marked by numerous economic, social and technological transformations gave us grounds to announce as a strategic production factor

Table 1

Functions and Criteria for Evaluating the Work of Marketing Unit Employees (Cherevko 2004)

\begin{tabular}{|c|c|c|}
\hline Position & Functions & Evaluation criteria \\
\hline Head of Unit & $\begin{array}{l}\text { Development of a marketing strategy; coordination } \\
\text { of marketing programs; control of achievement of } \\
\text { marketing plans and implementation of strategies }\end{array}$ & $\begin{array}{l}\text { Improved marketing strategies; increased } \\
\text { competitive power and weight of the } \\
\text { company }\end{array}$ \\
\hline Product Manager & $\begin{array}{l}\text { Development of production and pricing strategy; } \\
\text { identification of the product range. Introduction of } \\
\text { new products. Development of distribution network }\end{array}$ & $\begin{array}{l}\text { Increased incomes from products; higher } \\
\text { share of new products in stock }\end{array}$ \\
\hline Marketing Planning specialist & $\begin{array}{l}\text { Situational analysis; identification of marketing goals, } \\
\text { development of an action plan; study plan; monitoring } \\
\text { of implementation of the plan }\end{array}$ & $\begin{array}{l}\text { Achieved goal of the plan, improved } \\
\text { competitive positions of the company }\end{array}$ \\
\hline $\begin{array}{l}\text { Advertising and Public Relations } \\
\text { Specialist }\end{array}$ & $\begin{array}{l}\text { Development of the promotion complex strategy; } \\
\text { organization of advertising campaigns; organization of } \\
\text { public relations }\end{array}$ & $\begin{array}{l}\text { Increased buyers' awareness; involvement } \\
\text { of new buyers; improved image of the } \\
\text { company; increased efficiency of promotion } \\
\text { measures }\end{array}$ \\
\hline $\begin{array}{l}\text { Specialist for Marketing Research } \\
\text { and Information Support of } \\
\text { Marketing Activities }\end{array}$ & $\begin{array}{l}\text { Research of product consumers; monitoring of } \\
\text { competitors; strategic analysis of work conditions; } \\
\text { information support of marketing decisions }\end{array}$ & $\begin{array}{l}\text { Availability of a systematically updated } \\
\text { database; support of the information needs } \\
\text { of heads and specialists on individual } \\
\text { marketing functions }\end{array}$ \\
\hline
\end{tabular}


the knowledge obtained as a result of intellectual activities. Employees who have social knowledge and intellect are the most important competitive advantage of any company, but it is especially relevant in a company that provides advertising services. It is beyond any doubt that the uniqueness of advertising business is in the fact that its most important resource is people, and it is people that determine the marketing policy of the advertising agency (Mel'nikovich, 2009b).

With Ukraine's access to new market relations, new requirements for advertising and its creation as a process emerged. This marked the beginning of new development of advertising agencies as a new type of economic entities.

Table 2

\section{Correlation of Changes of Consumer Demand} and Company Strategy (Kotler, 2006)

\begin{tabular}{|l|l|}
\hline \multicolumn{1}{|c|}{$\begin{array}{c}\text { Dynamics of consumer } \\
\text { demand motivation }\end{array}$} & \multicolumn{1}{|c|}{ Marketing strategy changes } \\
\hline $\begin{array}{l}\text { A consumer gives } \\
\text { preference }\end{array}$ & $\begin{array}{l}\text { Management of product } \\
\text { improvement } \\
\text { Increase in the diversity of new } \\
\text { forms of service provision }\end{array}$ \\
\hline $\begin{array}{l}\text { Great profit can be } \\
\text { made from products } \\
\text { manufacturing }\end{array}$ & $\begin{array}{l}\text { Management of marketing and } \\
\text { distribution network } \\
\text { Bigger networks are opened and } \\
\text { sales network is expanded }\end{array}$ \\
\hline $\begin{array}{l}\text { Sharp increase in the share } \\
\text { of consumers' spending } \\
\text { on non-food products }\end{array}$ & $\begin{array}{l}\text { Incentives for increased } \\
\text { manufacturing through advertising } \\
\text { Wider diversity of non-food } \\
\text { products } \\
\text { Start of production of new consumer } \\
\text { goods and services }\end{array}$ \\
\hline
\end{tabular}

Increased efficiency of advertising activities is facilitated by creation of advertising agencies, which implement it at a high professional level by using more rational means and ensure high quality advertising. Advertising agencies play a positive role as qualified coordinators between trade and production in the interests of consumers and the entire society (Fig. 2-3).

Unlike in the developed economies, the history of Ukrainian advertising started not a century and a half ago but only in 1991. This was the time when the first domestic agencies appeared as well as the pricing network on TV accompanied by more efficient options for information

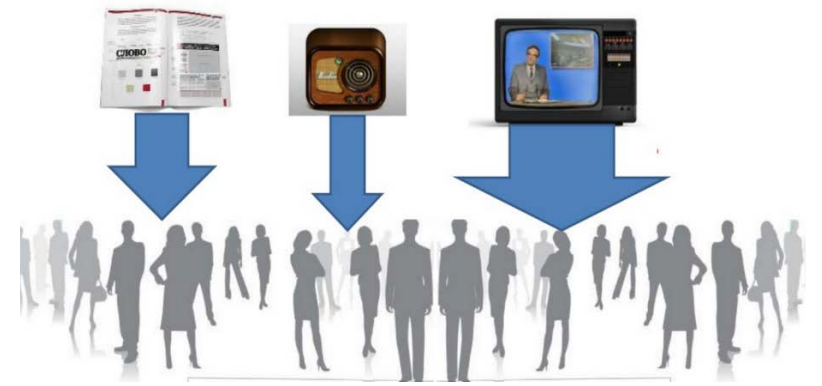

Fig. 2. Communication Model Yesterday dissemination. Expansion of foreign goods stimulated rapid development of advertising in the territory of Ukraine (Ronald Lane \& Thomas Russell, 2004)

Today, advertising budgets in Ukraine are managed by approximately 20 powerful network agencies represented by the interests of the world's largest advertising groups. These include: PROVID/BBDO, LeoBurnett, DDB,GreyKiev, Ogilvy\&Mather, Аінія 12, Visage, ArcJVT, Saatchi\&Saatchi, Aovertising, UMC and others.

\section{Trends in World Advertising Market}

In industrially developed countries, large sums of money are spent on advertising, and hundreds of thousands of people are involved in the advertising business. For instance, in the USA, which has the most developed advertising market, the advertising per capita cost totals nearly USD 1,000-1,500, whereas in Russia this figure is approximately USD 20-50, and in Ukraine it does not exceed USD 0-12. This shows that the advertising services market in Ukraine is underdeveloped and the management systems of the companies that work in this market are imperfect.

According to the estimations of Zenith Optimedia, the contribution of developing states to the growth of the global advertising market will total approximately $63 \%$ from 2012 to 2015 , and their share will increase from $34 \%$ to $38 \%$.

The fastest growth will be demonstrated by the markets in Latin America, "rapid" Asia, Eastern and Central Europe - on average, $10-11 \%$ every year in 2012-2015. However, regardless of this trend, the largest amounts of new dollars will still be invested in advertising by the USA; from 2012 to 2015 , its contribution will be $28 \%$ of the additional $\$ 76$ billion that will come to the global market.

From 2012 to 2015, there will be changes in the rating of the world's largest advertising markets. The USA, Japan, China and Germany will remain the top four leaders, whereas Australia and South Korea will take the eight and the tenth places respectively. At the same time, Great Britain will descend from the fifth to the sixth place, France - from the seventh to the ninth, and Canada will leave the top ten altogether. Instead, Brazil will grow to the fifth position, and Russia will join the top ten and take the seventh place.

Strengthening of the global economy will open up more opportunities for business development. Advertising is an important tool for launching new products and entering

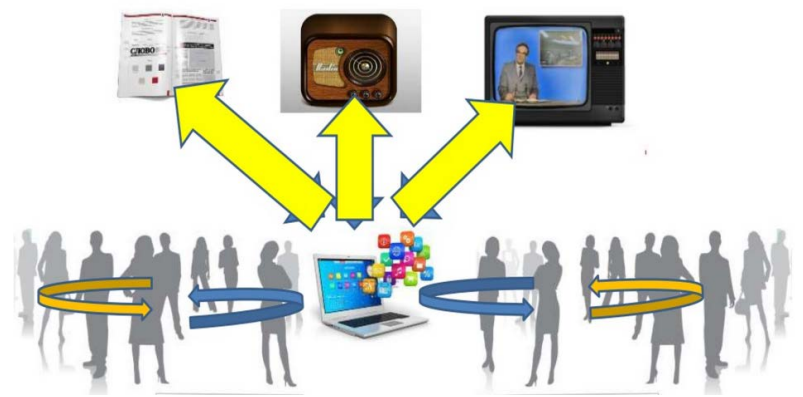

Fig. 3. Communication Model Today 
new markets so the advertisers will increase their budgets wherever they will receive a significant effect from these investments. As a result, the interest in managing the process of provision of advertising services will grow. Recently, numerous works have been dedicated to the problems of advertising business management - from articles to monographs and manuals. This problem has been studied by many foreign and domestic researchers such as D.A. Aaker, R. Batre, J. Burnet, F. Jefkins, S.V. Veselov, V.V. Gnatushenko, V.M. Dem'yanov, S.V. Dinchev, L.Yu. Zayatin, W.R. Lane, Yu. G. Lysenko, G.K. Russell, Ye.V. Romat, S.V. Chelakhov and others. Some publications by practicing advertisers can be found on professional advertising portals and in professional marketing and advertising periodicals.

Table 3

Top-10 Advertising Markets

\begin{tabular}{|c|c|c|c|c|c|}
\hline \multicolumn{2}{|c|}{2012} & Adspend & \multicolumn{2}{|c|}{2015} & Adspend \\
\hline 1 & USA & $161 \mathrm{Z41}$ & 1 & USA & 182427 \\
\hline 2 & Japan & 51724 & 2 & Japan & 53453 \\
\hline 3 & China & 36190 & 3 & China & 48678 \\
\hline 4 & Germany & 25646 & 4 & Germany & 27155 \\
\hline 5 & Great Britain & 19502 & 5 & Brazil & 23901 \\
\hline 6 & Brazil & 18217 & 6 & Great Britain & 20689 \\
\hline 7 & France & 13525 & 7 & Russia & 13714 \\
\hline 8 & Australia & 12633 & 8 & Australia & 13658 \\
\hline 9 & Canada & 11325 & 9 & Canada & 13456 \\
\hline 10 & South Korea & 10899 & 10 & South Korea & 13303 \\
\hline
\end{tabular}

Million US dollars, current prices. The amounts are shown as calculated on the basis of the average exchange rate as of 2011 (Telekritika, 2013)

However, the advertising services market still lacks publications on the problems of management of an adverting agency marketing, and there is no uniform interpretation of the category of "advertising agency marketing management" as such. In general, this problem has not been subject to extensive scientific analysis, which fact necessitated this article.

Nevertheless, the theory of advertising business management demonstrates a number of problems that require further solution, including the optimal organizational structure of advertising agencies, improvement of the mechanism of interaction of the advertising process participants, and development of efficient mechanisms for managing the process of provision of advertising services (Cherevko, 2004).

\section{Marketing agency process, and a role of marketing in it}

First, let us look at the structure of management of the agency marketing process and the place and role of the marketing unit in it. Agencies can be of various sizes: they may have from several to dozens and hundreds of employees. Agency management may opt for various organizational management structures. According to (Romat, 2008; Ronald Lane \& Thomas Russell, 2004) and our observations, the most typical structural units existing in universal and in many specialized agencies are: Customer Service Department (Department of Orders), Creative Department, Marketing Department, Research Department (Department of Marketing Research), Department of Public Relations (PR-Department), Department of Media Planning (Media Department, or Advertising Department, or Department for Planning and Media Relations), Department for Production of Advertising and Other Materials (Production Department), Department for Implementation of Projects or Operating Department, Business Development (New Business Department or Commercial Department), Department of Corporate Communications, Department of Strategic Planning, Information Technology Department, Legal Department, Human Resources Department, Financial and Economic Department. Not all of these departments can be found in each type of agency. Depending on the type of services the agency is going to offer its customers, it can include such units and functions that will be immediately involved in advertising product manufacturing:

- Agency Director. May be an individual or a collective entity;

- Creative Department - a unit responsible for the development of ideas, creative processes based on the strategy identified by the Strategic Planning Department. It has copywriters (responsible for the textual part of advertising), art directors (visual part), and graphic designers. The unit head is the Creative Director.

Customer Service Department is a group of managers acting as a link between the customer and the advertising agency. This includes Strategic Planning Managers, who are responsible for communication planning. The unit works closely with consumer research and develops the strategy for the future advertising campaign (Gorlov, 2007).

Depending on the internal structure, specialists identify several components of the advertising agency management complex:

1. Creative team management. This component is part of the human resources policy, but since creative professions constitute the main part of the agency personnel, or at least the most important part of it, they are to be worked with separately even when they simply develop label inscriptions. The success of an advertising agency will be determined primarily by the creative personnel.

2. Advertising service management.

3. Monitoring of orders performance and quality control.

The specific features of agency management are largely related to the specific nature of the type of companies themselves and their products. Most often, the principal activities include production of an advertising message. Yet, it can be done in various forms using various communication systems. The manager must take into consideration all the facts, know the target audience, specific features of the manufactured product, and market specifics. Then, with due regard to this information, the 
policy of the work of the entire organization is developed.

Advertising is entrepreneurial activity with a high level of risk. This should also be taken into account by a venture company manager. A good manager minimizes the risks, and only then strives to increase profits.

Recently, innovative approaches to business management have become more and more popular. The epoch has changed. Now, entirely different factors influence the decision-making process compared to 10-20 years ago. Management based on fear no longer works. The manager's personal characteristics as well as his/her ability to lead come to the fore, while the job description and formalities become less important. Non-standard views on the management, initiative and enthusiasm in everything are encouraged.

Today, interesting and relevant ideas of business conduct can most frequently be found in representatives of such countries as the USA, Sweden, and France. This can be explained by the presence in them of a large number of business schools and other specialized business institutions.

Swedish economists and professors of the Stockholm School of Economics, Kjell Nordstrem and Jonas Ridderstrale, wrote the manifesto of a new era of business ten years ago, yet in our countries their ideas became popular not so long ago.

The main ideas of Nordstrem and Ridderstrale include: - Globalism. Wider and wider spread of the Internet, cosmopolitanism, exchange of experience, and corporate mergers.

- Constant search for business differentiation. You should create something new, something still unknown in the world, or look for some competitive advantage.

- The need for an innovative organizational structure. Create conditions that ensure production not of the same goods but an uninterrupted flow of creative ideas.

- Leadership. Only a charismatic and confident leader can motivate his/her subordinates to move towards new professional achievements.

- Freedom of power. An opportunity to freely use the most valuable resource - human mind.

- The ability to surprise people. The only way to sell your product is by surprising the consumer and by making him/ her interested.

- Presentation of business as show business. Nothing draws attention as much as a creative and non-standard approach. It is most obvious in show business. This means you should take some elements of a show and adapt them to your business.

These and many other ideas form no longer new but very relevant understanding of the modern business structure and development (Nordstrem \& Ridderstrale, 2006).

In practice, with regard to real management of advertising agency marketing, these principles can be used as follows.

The use of appropriate management in advertising is important as in no other business, because the tasks of the agency are in many aspects identified by the consumers and not by the producers of advertising services. The most important is the customer and the end consumer.
Today, the agencies have to constantly create the woweffect both in their products and in the development of their image. Significant success in this respect was achieved by Ogilvy \& Mother Ukraine, whose flamboyant advertising campaigns produced a powerful creative image.

Nordstrem and Ridderstrale recommend being faster with your plans and actions. Every day someone has an idea that we could implement, and the longer we wait the more opportunities we lose. For advertising agencies, this piece of advice is extremely relevant, since trends are constantly changing very rapidly. A successful agency does not follow but dictates the trends itself.

In advertising as in many other types of business, there is a notion of competitive bidding. This is a competitive form of provision of services or performance of works on the basis of pre-defined documented conditions, within the agreed timelines according to the principles of competition, justice, and efficiency. A contract is signed with the winner of the competitive bidding process - the participant who submitted a proposal that meets the requirements of the documents and offers the best terms.

Agencies constantly participate in such competitions. Most of their time is spent on the development of bidding proposals. Today, doing one's job well is not enough; one should seek the ways to distinguish oneself, to surprise the customer and the end consumer. The brighter the way the agency presents its ideas, the higher the probability that it will get the order to produce a video or perform other works.

Today, for the presentation of ideas not only Power Point is used but also more modern means such as Kinekt or augmented reality applications. Kinekt enables a user to interact with the application using oral commands, body movements, objects, etc. Augmented reality applications help you combine the virtual and real thus creating a brighter impression on the customer made by your presentation.

\section{Their Marketing Tasks}

In Ukraine, universal and specialized agencies solve various marketing tasks aimed at ensuring the agency development. According to the results of the survey that we conducted, the most popular among them (in decreasing order) are search for new customers, identification of positioning, development strategy drafting, identification of the agency's pricing policy, planning of the range of advertising services, market behavior monitoring, and other services.

Somewhat different priorities among representatives of advertising agencies were developed with regard to those marketing tasks that they are planning to perform in the future. The first place in terms of priority is taken by the implementation of PR-measures to promote advertising services and organize participation in various advertising festivals/contests. The second place is taken by the evaluation of efficiency of marketing activities that 
the agencies are planning to implement to evaluate their advertising activities in the marketing communications market. The third place with regard to the need to implement by the agency is taken by the identification of its pricing policy and monitoring of the market behavior of the agency's competitors.

Management of an advertising agency requires not only special knowledge of the media, creative and production spheres of advertising, but also the ability to understand creative people who create advertising. If we analyze activities of modern advertising agencies, we can come to a conclusion that they are no longer companies but creative laboratories, whose success depends on the presence or absence of a creative person. Agencies are being transformed into a productive process that requires not only nice creative solutions but also efficient operations management.

With regard to human resources issues, in order to retain personnel in the agency you have to make them interested. Financial interest is not always the key. In advertising agency marketing management, a very important role is played by its head, his/her charisma and leadership qualities. The head has to be a role model for his/her subordinates. Many creative directors make their employees believe in themselves and respect what they are doing. The most spectacular examples that I know include: former Creative Director of Adventa Lowe Oleksii Pasichnyk, Head of Think!McCannEricson Yevhenii Kaminskyi, former Creative Director of Havas Worldwide Kiev Serhii Kryvosheia, and its current Creative Director Kostiantyn Sobol. These persons are good examples of head of an advertising agency.

The employees have to believe in their own strengths and success. By delegating powers and trust one can ensure initiative and respect. Each employee has to be aware of the agency's goals and feel his/her responsibility for the final product. This is the main task of a manager.

The basis for success is now the stability of quality, which is achieved through strategic planning, efficient management, fine-tuned search system and talent retention, etc. To this end, the leading Western European and Russian agencies create the position of Quality Assurance Manager, who introduces the standards of quality of service provision to customers. For instance, Russian agency Movie has a Quality Director in its staffing list. In our opinion, Ukrainian agencies should also introduce such positions, especially at the stage of standardization of their services (Mel'nikovich, 2009a; Mel'nikovich, 2009b).

\section{Conclusions}

Generalizing our analysis of marketing management in the advertising sphere, the following conclusions can be made:

1. Each agency in Ukraine has its own unique functioning characteristics, its own service portfolio, its own view of the managers as to how the agency should be organized that leads to the emergence of difference organizational structures of management even in agencies with the same specialization;

2. The majority of agencies have a non-systemic approach to organization of agency marketing, which results in sporadic activities related to the application and organization of marketing in the agency. Only some individual agencies begin to develop their own marketing strategies, for the implementation of which marketing budgets are allocated;

3. Responsibility for the implementation of certain marketing tasks in the agencies is dispersed among various structural units and even among individual employees. For instance, the issues related to the agency development strategy drafting, identification of the marketing budget, agency positioning, and its pricing and products range policies are the responsibility of the owner or head of the agency. Search for new customers is the responsibility of the Customer Service Department or Business Development Department. Monitoring of market behavior or competitors is performed by the Marketing Department or Research Department, whereas promotion and PR event for promotion of advertising services may be organized and carried out by the Corporate Communications Department, Marketing Department, Business Development Department or even by the owner (head) of the agency. Such situation in the marketing management sphere, which has developed in Ukrainian advertising business, demonstrates a lack of agencies' readiness for the implementation of a comprehensive system approach to organizing their marketing activities.

4. Compared to highly developed countries, the Ukrainian advertising market is far from saturation and has a great development potential. Further development of the advertising market can be determined by development of other commodity markets, primarily an increase of the volume of the consumer goods market. The growth of the market of consumer goods and services, appearance of new brands influence the growth of the volumes of the advertising market.

Ukrainian companies, based on the experience of foreign companies, use the same business technologies as the world companies, but not in the quality and amount as in the world.

The modern market of media services is influenced by a range of factors. The most influential among them are: increased competition, governmental regulations, deficit of highly qualified specialists. Among the problems of both advertising industry and the Ukrainian business in general one should also mention a chronic shortage of primary marketing information associated with the closeness of most Ukrainian companies (turnover, profit, costs of the brand launch, advertising, etc.). 


\section{References}

Romat, E.V. (2008) Advertising marketing system, Studcentr, St. Petersburg, Russia, 608 p.

W. Ronald Lane and J. Thomas Russell (2004) Advertising, Translated by Vinogradova T., PITERS, - St. Petersburg, Russia, $537 \mathrm{p}$.

Cherevko, V.B. (2004) "Synthesis enterprise management system that provides advertising services" Abstract of Ph.D. dissertation, economic sciences, Donetsk National University, Donetsk, 16 p.

Ortins'ka, V.V., Dubovik, T.V., Dubovik, O.V. (2003) "Problems of evaluating the effectiveness of advertising on the management of commercial enterprises" Marketing in Ukraine, Vol. 6, pp. 121-125.

Mel'nikovich, O.M. (2009a) "Study trends advertising development agencies in Ukraine" Marketing research in Ukraine, Vol. 1, pp. 62-67.

Mel'nikovich, O.M. (2009b) "Marketing companies advertising industry": D. Sc. Thesis Kiev, Kyiv National University of Trade and Economics, Ukraine, $467 \mathrm{p}$.

Kotler, F. (2006) "Principles of Marketing", available at: http://bibliograph.com.ua/biznes-42/7.htm (Accessed 12 April 2015).

Telekritika (2013) "Global advertising market, forecasts of network advertising agency", available at: www.telekritika.ua/rinok/2013-04-30/81343, (Accessed 12 April 2015).

Gorlov, O. (2007) "Global advertising market, forecasts of network advertising agency" available at: http://www.training.com.ua/article/8/Osoblyvosti_ukrainskoi_reklamnoi_industrii.html

Nordstrem, K. and Ridderstrale, J. (2006) Funky Business. Capital is dancing to the tune of talent, St. Petersburg, Russia, $135 \mathrm{p}$.

\section{Денис КИСЛОВ, Евгения ГОРОБЕЙ \\ УПРАВЛЕНИЕ МАРКЕТИНГОМ РЕКЛАМНОГО АГЕНТСТВА}

Аннотация. Цель работы. Статья направлена на определение сущности, особенностей и факторов управления маркетингом рекламного агентства. Одним из средств является применение нестандартных подходов в управлении деятельностью рекламных агентств, что при определенных условиях позволяет улучшить ситуацию и вывести агентство на новый более высокий уровень, позволит повысить эффективность его функционирования в условиях трансформационной экономики Украины. Методика. Мониторинг рыночного поведения агентств по продвижению рекламных услуг. Результаты мониторинга и анализа установили, что большинство агентств имеют бессистемный подход к организации маркетинга в агентстве, в результате чего проводят спорадической активности по применению и организации маркетинга агентства. Лишь отдельные агентства переходят к формированию собственной маркетинговой стратегии, для реализации которой выделяют маркетинговые бюджеты. Определены основные маркетинговые функции рекламного агентства Украины. Практическое значение. Быстрое развитие технологий, усложнение и разнообразие товаров и услуг, сокращение их жизненного цикла, повышение требований покупателей, увеличение объемов и скорости получения информации, рост конкуренции - все эти изменения, происходящие во внешней среде, заставляют украинские предприятия, предоставляющие рекламные услуги, искать новые подходы для лучшей адаптации к этим условиям. Неопределенность, непредсказуемость и нестабильность внешней среды будут расти и дальше. Итак, предприятиям, предоставляющим рекламные услуги необходимо постоянно адаптироваться не только к действительным условиям, но и обеспечить способность к быстрому реагированию на будущее. Основой успеха становится стабильность качества, что достигается стратегическим планированием, налаженной системой поиска? эффективным менеджментом, что побуждает внедрять должность директора или менеджера по качеству, который должен заботиться стандартам качества в обслуживании клиентов. Согласно мониторинга агентства переходят к формированию собственной маркетинговой стратегии, для реализации которой выделяют маркетинговые бюджеты, будет способствовать поиску новых клиентов. Значение/оригинальность. Полученные данные дальнейшее развитие рекламного рынка может определяться развитием других товарных рынков, в первую очередь, увеличением объемов рынка товаров массового потребления. 